\title{
3 \\ Tasmania in the 19th and early 20th centuries
}

To set a context for the analysis presented in this book, this chapter provides a brief history of Tasmania in the 19th and early 20th centuries, examines changes in its population size and structure and looks at some characteristics of Tasmanian society that are relevant to theories of fertility decline: religion, education and literacy, occupation and urbanisation. Detailed population data are presented for the years 1861, 1870, 1881 and 1891 to provide a comparison with data for couples marrying in $1860,1870,1880$ and 1890 who are the subject of the fertility analysis that follows.

Many of the data in this chapter are derived from the Tasmanian population censuses. Legislation for the first Tasmanian census was introduced by Lieutenant-Governor of Tasmania John Franklin in 1841 (Kippen 2002c). These censuses were conducted in 1842, 1843, 1848, $1851,1857,1861,1870,1881,1891$ and 1901. This chapter uses the published tables from these censuses, since the original records were destroyed (TAS 1842, 1857, 1861, 1870, 1881, 1891, 1901).

\section{Tasmania's history, 1803-1914}

Tasmania is an island of just less than 68,500 square kilometres, situated 240 kilometres off the south-east coast of mainland Australia. The first European to sight it was Dutch explorer Abel Tasman, in 1642, who named it Van Diemen's Land (Boyce 2010; Reynolds 2012). The British established a penal colony on the island in 1803 on the Derwent River 
near present-day Hobart, 15 years after the establishment of the penal colony in Sydney, NSW. The two major cities, Hobart and Launceston, were established three years later, in 1806. Van Diemen's Land was part of the colony of New South Wales until it became a separate colony in 1825 (Boyce 2010). The British transported convicts to Van Diemen's Land for almost 50 years, until the convict system was disbanded in 1853 .

In its early years, the colony was administered by a series of lieutenantgovernors under the authority of England. The Australian Colonies Government Act of 1850 established 'a partially elected legislature with a limited franchise', which subsequently drafted the Tasmanian Constitution (Boyce 2010: 241). Self-government was introduced on 1 January 1856 and the colony's name was changed to Tasmania. There were two houses of parliament, the upper house (or legislative assembly) and the lower house (house of assembly). The franchise was restricted throughout the second half of the 19th century, since men were eligible to vote only if they had property of a certain value. In 1901, Tasmania became a state of the Commonwealth of Australia, following the federation of the six mainland colonies. With Federation, all males 21 years of age and older became eligible to vote (Reynolds 2012). The right to vote was given to all women aged 21 years and older in 1902 for federal elections and in 1903 for state elections.

The colony grew spectacularly in the first 50 years, partly because of the availability of convict labour and investment from England. The British army was a presence in Tasmania throughout the early years until they left the island in the early 1870 s.

The colony's economy was predominantly agricultural in its earliest years, mainly sheep farming but also cattle, wheat, dairy farming and other agricultural produce. The land was very fertile, there was plenty of clean water and the climate was temperate (Boyce 2010). Wool was a major export for much of the 19th century; at the end of the 1860s, for example, wool accounted for about half of Tasmania's export income (Reynolds 2012). Timber-cutting was also an important industry in Tasmania's early years (Robson and Roe 1997).

In the 1820s and 1830s, many of the British immigrants obtained large landholdings in Tasmania's fertile Midlands and in the river valleys south of Launceston through free grants or purchase at cheap prices. These landholders became the Tasmanian 'gentry', who used cheap 
convict labour to develop and maintain their properties (Reynolds 1969; Appendix D: Story 1, this volume). In the early years of the colony, the government granted small landholdings to pardoned convicts and, while many of these were forfeited or sold, several small farms and commercial gardens remained close to the two major cities.

Shipping was another important area of economic activity in the colony from its earliest years, since Hobart was on the major sea routes between the other colonies of Australia and the rest of the world. Ships sailed frequently from Hobart and Launceston to Melbourne, Sydney, Brisbane and New Zealand, carrying both goods and people. In later years, additional routes were added to Adelaide and Fremantle.

Shipbuilding was an important industry in the colony from the early years and increased in importance during the 1830s (Reynolds 2012). During the late 1820 s and early 1830 s, many manufacturing ventures were set up in Hobart and Launceston, such as soap and candle-making, small breweries and mills.

From the early days of settlement, Hobart's population was in communication with other colonies and other parts of the world. By 1834, Hobart had 'six newspapers, two advertising papers, one official gazette, one magazine and two pocket almanacks' (Haynes 1976: 13). The Hobart newspapers often contained long articles about events in Britain, Europe and the rest of the world, sourced from the British newspapers, which arrived with the ships. If they had the means, people could subscribe to Hobart's reading rooms, where they were able to access many overseas journals and papers (Reynolds 2012).

When transportation of convicts ceased in 1853, money stopped flowing from England. In 1856, a depression set in and did not lift until the discovery of minerals in the early 1870 s (Reynolds 2012). There was a decline in shipbuilding and whaling in the 1860s and early 1870s, but, from the mid-1870s, new agricultural industries of hops, fruit-growing and jam-making began to make a substantial contribution to the colony's economy (Meikle 2010). From the late 1870s, the manufacturing industry began to expand to include products such as furniture, biscuits, shoes and clothing (Reynolds 2012). A large brewing company was set up in Launceston in the early 1880s. 
By the middle of the 19th century, most of the largest rural estates were owned by families who had obtained the land before the 1830s (Reynolds 1969). These families often intermarried, concentrating land in the hands of these large landowners. The Waste Land Act of 1858, however, changed the pattern of landholding in the colony, since it brought the purchase of land within the reach of working men and women with some savings (Meikle 2011). 'Selectors', as these farmers were known, moved into areas of Crown land all over the colony, but particularly on the north-west (Appendix D: Story 2) and north-east coasts and in the Huon Valley south-west of Hobart. Many small farming communities were established in these areas in the late 19th and early 20 th centuries.

The long depression that started in 1856 began to end with the discovery of tin in the north-west of the island in 1871 and the building of a smelter in Launceston by the Mount BischoffTin Mining Company in 1874. Over the decade there were also discoveries of gold, silver, bismuth, antimony, coal and copper in other parts of the island. There were, however, even greater discoveries on the west coast of Tasmania in the 1880s and 1890s, which led to the development of silver mines in Zeehan from 1882 and gold and copper mines in Queenstown from the 1890s. There was a large movement of the population to these mining areas and settlements grew around the mines - of both miners and their families (if the family moved with them) and workers to service the populations.

Communication within Tasmania improved in the late 1850s with the completion of an electric telegraph line between Hobart and Launceston in 1857, which was soon extended to George Town on the north coast (Cox 2012). A telegraph line was set up between Tasmania and Victoria in 1859, but this did not work properly, and it was not until 1869 that an effective line was set up between the two colonies. Communication with the rest of the world improved dramatically when the telegraphic cable was permanently established between Tasmania and London in 1872. From this time on, Tasmanian newspapers were able to publish news from around the world, particularly articles and reports from the English newspapers, with very little delay. During the 1870s, telegraph lines were extended throughout Tasmania. Telephone exchanges were opened in Hobart and Launceston in 1883, but telephone connections were uncommon and the use of telephones very limited until the 1920s (Reynolds 2012). 
The railways came relatively late to Tasmania. The first railway line, from Launceston to Deloraine, was opened in February 1871 and the first train between Hobart and Launceston ran five years later, in November 1876. In 1883, the government constructed railway lines from Launceston to Scottsdale and from Deloraine to Devonport (Reynolds 2012). In 1892, railways lines were built from Strahan to Queenstown in the far west and from Zeehan to other mining areas (Robson and Roe 1997).

In the late 1870 s and early 1880 s, tourism became an important industry for Hobart, with visitors from Melbourne and Sydney spending their summer holidays in the town and surrounding areas (Bolger 1978). For almost 20 years, Hobart was a favoured destination of tourists and invalids.

The 1880s was a prosperous decade for Tasmania: the mining industry grew and the economy of the colony expanded. By the beginning of the 1880 s, the income obtained from exporting minerals was greater than that obtained from wool exports (Reynolds 2012). When minerals were first discovered, numerous small mining companies were established, but they were quickly absorbed into large mining enterprises, such as the Tasmania Mine in Beaconsfield.

The power and influence of the landed gentry declined markedly from 1875 (Reynolds 1969). Wool ceased to be a dominant commodity and the economic importance of the large landowners declined. In the period 1875-80, wool accounted for 40 per cent of Tasmania's total export income, but this had fallen to 14 per cent in 1895-1900. By the beginning of the 20th century, the agricultural produce of the small farms in northwestern Tasmania had become more valuable than the Tasmanian wool clip, while the orchards of the Huon Valley had become famous for their output of apples, pears, berries and other fruit (Reynolds 2012).

As in all other Australian colonies, except Western Australia, an economic depression struck in the early 1890s. In Tasmania, the depression started with the failure of the Van Dieman's Land Bank in August 1891 (Robson and Roe 1997). Unemployment rose and there was an increase in families seeking food, clothing and fuel from charitable organisations. Public works were commenced to provide more employment. Economic conditions improved during the 1890s with the mining discoveries in the far west and the building of a new smelter for production in Mount Lyell 
(Queenstown). Exports of minerals, but also of timber, boomed (Robson and Roe 1997). By the end of the 19th century, more than half the value of Tasmanian exports was derived from four minerals: copper, tin, gold and silver.

An analysis of raw wages of 'urban' carpenters, bricklayers, masons and blacksmiths in Tasmania shows they increased steadily through the 1880s, but there was a sharp drop in the early 1890s (Famour and Withers 2014). However, by 1900, raw wages for carpenters and bricklayers were back to the levels of the 1880s, while wages for masons and blacksmiths had improved somewhat. The wages of farm labourers and shepherds also fell sharply between 1892 and 1893; they increased until 1900, but not to their former level.

Launceston was the first city in the Southern Hemisphere to have electric light, in 1895, followed by Hobart in 1898 and Zeehan in 1900 (Robson and Roe 1997). Both Launceston and Hobart had been lit by gas since the late 1850s. In 1893, Hobart became the first city in the Southern Hemisphere to have an electric tram network. Bicycles also became a popular form of transport in the 1890s and 1900s for both men and women. Agriculture became more mechanised in the late 19th and early 20th centuries, with the introduction of steam-driven threshing machines (Pink 1990).

Tasmania was generally prosperous in the early years of the 20th century leading up to World War I (Roe and Robson 1997). Mining prosperity lasted until the beginning of the war and jam-making and fruit production were also very important during the first decade of the 20th century. With Federation in 1901, the federal government embarked on a construction program of federal buildings in the state (Reynolds 2012). Federation also brought in free trade with the mainland, which lowered the cost of imported goods but increased competition with Tasmanian produce and manufactured goods. The states, however, were protected from the impact of free trade in the early years of the 20th century, with the federal government returning three-quarters of the customs and excise revenue to the states for the first 10 years. 


\section{Population size and composition}

\section{$1803-1860$}

In the first 30 years of European settlement, Tasmania's Indigenous population, which was estimated to be about 7,000 in 1817, decreased dramatically, mainly due to massacre by the European population (Boyce 2010). Fewer than 250 of the original inhabitants remained by 1830 (Kippen 2002c). There is little information on the size of the Tasmanian Indigenous population in the 19th and early 20th centuries, since Aboriginal people were not counted in the Tasmanian population censuses. ${ }^{1}$

From 1803 to 1822, the European population grew to 8,422 inhabitants (Table 3.1), 58.1 per cent of whom were convicts, 16.9 per cent of whom were 'free by servitude of pardon' and 25 per cent of whom were free settlers (Borrie 1994: 40). There was a marked imbalance of the sexes in the very early years of the colony among the adult convict population. Between 1821 and 1825 , for example, only 8.6 per cent of the 6,101 convicts who arrived in the colony from Britain were female (Borrie 1994: 28).

The population grew rapidly between 1822 and 1842 (Table 3.1). There were increasing numbers of free settlers coming to the colony, with about 11,000 arriving in the 1830s (Robson and Roe 1997). In 1842, convicts made up a smaller proportion of the population than in 1822 , accounting for 36.6 per cent of males and 13.2 per cent of females (TAS 1842). Another 7.9 per cent of men and 2 per cent of women were 'ticket-of-leave' - that is, they were convicts on parole (Alexander 2014: 36). Among the remainder of the population: 15.9 per cent of males and 36.1 per cent of females were born in Tasmania; 19.6 per cent of males and 37.8 per cent of females arrived in the colony as free settlers, either from other colonies or from other countries; and 20 per cent of males and 11 per cent of females were 'other free', presumably ex-convicts. It is important to note, however, that the census underreported the convict population, since there was a strong tendency for convict ticketof-leave holders to represent themselves as free persons (Kippen 2002c; Alexander 2014).

1 There were 19,625 Aboriginal and Torres Strait Islander people in Tasmania in 2011, accounting for 4 per cent of the Tasmanian population (ABS 2011). 
Table 3.1 Population of Tasmania: 1822, 1832, 1842 and 1857

\begin{tabular}{|l|r|r|r|r|r|}
\hline Year & \multicolumn{1}{|c|}{1822} & \multicolumn{1}{|c|}{1832} & \multicolumn{1}{c|}{1842} & \multicolumn{1}{c|}{1851} & \multicolumn{1}{c|}{1857} \\
\hline Males & n.a. & n.a. & 39,604 & 44,080 & 45,916 \\
\hline Females & n.a. & n.a. & 17,816 & 25,482 & 34,886 \\
\hline Military $^{1}$ & n.a. & n.a. & n.a. & 568 & 690 \\
\hline Total & 8,422 & 25,318 & 57,420 & 70,130 & 81,492 \\
\hline
\end{tabular}

n.a. not available

${ }^{1}$ Military includes wives and children for whom no details were given.

Sources: Borrie (1994: 40); TAS (1842, 1851, 1857).

There was still a marked imbalance in the sexes in 1842 . There were 223 males for every 100 females in the total population of the colony (TAS 1842). The convict population, however, was much more imbalanced, with 617 male convicts for every 100 female convicts.

By 1857 , the colony's population had grown to 81,492 (Table 3.1). This census year was the last in which the population was categorised according to its 'free' or 'convict' status. In 1857, convicts or ticket-of-leave holders made up only a very small proportion of the adult population (excluding the military): 4.7 per cent of males and 2.5 per cent of females (TAS 1857). About one-third of adult males (33.7 per cent) and 18 per cent of adult females were ex-convicts. Most of the total population-61.7 per cent of males and 79.5 per cent of females-were either free settlers or born in the colony. Just over one-third of the total population (37.3 per cent) in 1857 was born in Tasmania: 32.5 per cent of men and 43.7 per cent of women. Some of those born in the colony would have been the children of former convicts.

There was a marked imbalance of the sexes in 1857 among unmarried males and females aged 14 and over, with 2.64 males for every female (McDonald 1974); however, the imbalance was far greater in the areas outside Hobart, where the ratio was 3.80, than in Hobart and surrounding districts, where it was 1.18 .

While free settlers continued to arrive from Britain in the 1840s and 1850 s, the colony also lost population during the period, mainly to the colony of Victoria. The outflow of population began in the late $1840 \mathrm{~s}$ and increased markedly during the Victorian goldrush in the mid-1850s (Reynolds 2012). 


\section{$1861-1911$}

Between 1861 and 1901, Tasmania's population almost doubled, from around 90,000 to 172,500 (Table 3.2). Between 1861 and 1879, net migration to Tasmania was negative-that is, more people left the colony than settled there (Table A3.1). Many Tasmanians went to New Zealand in the early 1860s with the discovery of gold in Otago (Kellaway 1999). However, in the 1880 s, more people settled in the colony than left, probably due to the mining boom, while in the 1890s the numbers of those settling in the colony were about the same as those who were leaving. Many Tasmanians went to Western Australia in the late 1890s and early 1900s, attracted by the discovery of gold in that colony.

Table 3.2 Population of Tasmania: 1861, 1870, 1881, 1891, 1901 and 1911

\begin{tabular}{|l|c|r|r|r|r|r|}
\hline Year & \multicolumn{1}{|c|}{1861} & \multicolumn{1}{c|}{1870} & \multicolumn{1}{c|}{1881} & \multicolumn{1}{c|}{1891} & \multicolumn{1}{c|}{1901} & \multicolumn{1}{c|}{1911} \\
\hline Males & 49,593 & 52,853 & 61,162 & 77,560 & 89,624 & 97,591 \\
\hline Females & 40,384 & 46,475 & 54,543 & 69,107 & 82,851 & 93,620 \\
\hline Total & 89,977 & 99,328 & 115,705 & 146,667 & 172,475 & 191,211 \\
\hline
\end{tabular}

Sources: TAS (1861; 1870; 1881: 02_27; 1891: 01_xxxi; 1901: 02_xx); Commonwealth of Australia (1914b: 10-12).

The population of Tasmania was very young in 1861, with around half the female population and around 40 per cent of the male population under 20 years of age (Tables 3.3 and 3.4). Males had an older age structure than females, with the proportion of males over 40 years of age almost twice that of females.

The age structure of the female population changed little over the three decades, although the proportions of the female population in the age ranges 30-49 years fell slightly and the proportion 50 years and older increased (Table 3.3). While the census data for 1861 and 1870 present the population only by 10 -year age groups, estimated population data for females aged 15-49 years by five-year age groups show very similar trends (Appendix A: Table A.5). 
Table 3.3 Female population by age, Tasmania, 1861, 1870, 1881 and 1891

\begin{tabular}{|l|r|r|r|r|}
\hline Year & \multicolumn{1}{|c|}{1861} & 1870 & \multicolumn{1}{|c|}{1881} & \multicolumn{1}{|c|}{1891} \\
\hline Age & \multicolumn{4}{|c|}{ Percentage } \\
\hline 0-14 years & 42.1 & 45.3 & 39.8 & 41.00 \\
\hline 15-19 years & 9.7 & 9.8 & 12.2 & 9.90 \\
\hline 20-29 years & 17.7 & 14.1 & 17.9 & 18.30 \\
\hline 30-39 years & 14.0 & 11.8 & 9.6 & 12.10 \\
\hline 40-49 years & 9.3 & 9.1 & 8.7 & 7.40 \\
\hline 50+ years & 7.2 & 9.8 & 11.6 & 11.30 \\
\hline Not specified & 0.0 & 0.0 & 0.1 & 0.03 \\
\hline Total (\%) & 100.0 & 100.0 & 100.0 & 100.00 \\
\hline Total (no.) & 40,384 & 46,475 & 54,543 & 69,107 \\
\hline
\end{tabular}

Sources: TAS (1861; 1870; 1881: 02_27; 1891: 01_xxxi).

The age structure of the male population became younger over the three decades, with the proportion of males aged 20-29 years increasing and the proportion of males aged 30 years and older falling, particularly the age group 40-49 years (Table 3.4). Estimated population data for males aged 15-49 years by five-year age groups show the proportions of males in the age ranges 15-29 years increased between 1861 and 1891 while the proportions of males in the age range 35-49 years fell over the same period (Appendix A: Table A.6).

Table 3.4 Male population by age, Tasmania, 1861, 1870, 1881 and 1891

\begin{tabular}{|l|r|r|r|r|}
\hline Year & \multicolumn{1}{|c|}{1861} & \multicolumn{1}{|c|}{1870} & \multicolumn{1}{|c|}{1881} & \multicolumn{1}{|c|}{1891} \\
\hline Age & \multicolumn{4}{|c|}{ Percentage } \\
\hline 0-14 years & 35.0 & 40.4 & 36.6 & 37.4 \\
\hline 15-19 years & 6.8 & 8.1 & 11.0 & 9.1 \\
\hline 20-29 years & 12.0 & 10.7 & 16.4 & 18.6 \\
\hline 30-39 years & 16.1 & 9.8 & 9.2 & 13.2 \\
\hline 40-49 years & 14.8 & 11.9 & 8.2 & 7.5 \\
\hline 50+ years & 15.3 & 19.0 & 18.1 & 13.4 \\
\hline Not specified & 0.0 & 0.0 & 0.4 & 0.7 \\
\hline Total (\%) & 100.0 & 100.0 & 100.0 & 100.0 \\
\hline Total (no.) & 49,593 & 52,853 & 61,162 & 77,560 \\
\hline
\end{tabular}

Sources: TAS (1861; 1870; 1881: 02_27; 1891: 01_xxxi). 
In 1861, there were more than twice as many unmarried adult men in Tasmania as there were unmarried adult women. The ratio of unmarried males aged 15 and over to unmarried females of the same age was 2.1 for the colony as a whole, but varied markedly by geographic region, being 1.07 in Hobart and 2.72 in the rest of the colony (McDonald 1974: 55). In 1881 in Tasmania as a whole, the balance of the sexes in the 'marriage market' - measured as the number of unmarried males aged 17.5-49 years per 100 unmarried females aged 15-44 years (McDonald 1974) was still uneven at 110 . However, in Hobart, there were many fewer unmarried males than unmarried females, with a ratio of 61 unmarried males aged 17.5-49 years to 100 unmarried females aged 15-44 years (TAS 1881: 02_104). By 1891, the balance of the sexes in the marriage market had risen to 122 for Tasmania as a whole, while in Hobart the ratio of unmarried males to unmarried females had risen to 84 (TAS 1891: 04_61).

The proportion of the population born in the colony continued to increase in the final decades of the 19th century, with a corresponding fall in the proportion born in the British Isles (Table 3.5). In 1881 and 1891, the majority of those born in the British Isles-around 60 per cent-were born in England, while about 25 per cent were born in Ireland, 13 per cent in Scotland and 2 per cent in Wales (TAS 1881, 1891). The proportion of the population born in other Australian colonies was very small, although it increased slightly between 1870 and 1891 . More than half of those born in other colonies were born in Victoria (TAS 1891). Only a very small proportion of the Tasmanian population was born in a 'foreign' country. In 1881 and 1891, around one-third of this group was born in Germany and another third was born in China. By 1901, 79.3 per cent of the Tasmanian population was born in Tasmania, another 7.2 per cent was born in the other Australian colonies, while the proportion born in the British Isles had fallen to 11.8 per cent (TAS 1901: 02_xlv).

The increase in the native-born population and decrease in the proportion born in the British Isles are related to the age structure of the population. Younger Tasmanians were more likely to have been born in Tasmania, while a greater proportion of the older population comprised ex-convicts and free settlers from the British Isles. Consequently, the large majority of those marrying between 1870 and 1890 would have been born in Tasmania. 
Table 3.5 Birthplace of the Tasmanian population, 1870, 1881 and 1891

\begin{tabular}{|c|c|c|c|}
\hline Year & 1870 & 1881 & 1891 \\
\hline Birthplace & \multicolumn{3}{|c|}{ Percentage } \\
\hline Tasmania & 59.5 & 69.1 & 73.6 \\
\hline Other Australian colonies ${ }^{1}$ & 1.8 & 3.4 & 5.0 \\
\hline British Isles & 37.4 & 24.4 & 18.4 \\
\hline Other British possessions & 0.3 & 0.8 & 0.6 \\
\hline Foreign countries & 0.9 & 1.9 & 2.0 \\
\hline Not specified & 0.0 & 0.3 & 0.4 \\
\hline Total (\%) & 100.0 & 100.0 & 100.0 \\
\hline Total (no.) & 99,328 & 115,705 & 146,667 \\
\hline
\end{tabular}

1 Includes New Zealand

Source: TAS (1891: 04_71).

\section{Characteristics of Tasmanian society}

\section{Religion}

In the first decades of settlement, several religious denominations established ministries in the colony. The Church of England (or Anglican Church) was the established religion in Tasmania, with Robert Knopwood the first minister (Boyce 2010). The first Catholic priest arrived in the colony in 1821 and a Wesleyan missionary settled permanently in 1822 (Robson 1983). Both the Catholic and the Wesleyan churches were highly committed to working with convicts. The first Presbyterian ministry began in Hobart in 1823; a Congregationalist community was founded in Hobart in 1824, with a minister arriving in 1832, and the first Baptist church was established in Hobart in 1835.

The Nonconformist denominations made an important contribution to the intellectual life of the colony (Breward 1988; Robson and Roe 1997). The Presbyterians, Congregationalists and Baptists were often engaged in business or trade and were very important in founding community organisations such as libraries and the Mechanics Institute, 'where the respectable working man might read newspapers and attend improving lectures' (Robson and Roe 1997: 20). The Methodists were responsible 
for founding Hobart's first public library (Breward 1988). All religious denominations held Sunday schools where children received a basic education in the three 'Rs' (Breward 1993; Robson and Roe 1997).

Religious affiliation was collected in all 19th-century Tasmanian censuses, except in 1881. It is important to note these data were collected for the total population-that is, both adults and children-so differences in religious affiliation over time may be affected by differential changes in fertility among the various religious groups. The 1842 census did not collect religious affiliation from 17 per cent of the population, mainly convicts, so it is difficult to compare these data with the other census years.

The Church of England was the dominant religion in Tasmania in 1851 but the proportion of the population who were Anglican fell between 1851 and 1901 (Table 3.6). Catholics made up around one-fifth of the population in most census years. The arrival in Tasmania of nearly 10,000 convicts from Ireland between 1840 and 1853 markedly increased the Catholic population of the colony (Boyce 2010), but 'Van Dieman's Land was never as Irish or as Catholic as New South Wales' (Alexander 2014: 23). The proportion of Methodists increased between 1851 and 1901, as in the other Australian colonies (Breward 1988). The proportion of 'Other' religions also increased markedly over the period; the rise between 1870 and 1901 was due to an increase in the numbers of 'Mahommedans, Buddhists and other non-Christian sects' and the commencement of the Salvation Army's work in Australia in the 1880s (TAS 1891: 01_xlvii).

Anglicans had the lowest church attendance of all groups in 19th-century Tasmania, followed by Presbyterians (Breward 1988). The Irish Catholics who came to Tasmania in the 1840s had low levels of attendance at Masssimilar to those in rural Ireland (Boyce 2010). The Congregationalists, Methodists and Baptists were probably more committed to their faith than other Protestants because of the discrimination these religious groups had experienced in Britain (Breward 1988). The Nonconformist denominations became 'evangelical in emphasis and practice' from the 1870 s and even the Church of England had a strong evangelical wing (Evans 2005). Towards the end of the 19th century, some sections of the Protestant churches became increasingly more liberal, with efforts to 'adapt the Christian message to the findings of science and philosophy' (Breward 1993: 93). 
Table 3.6 Population by religion, Tasmania, 1842, 1851, 1861, 1870 and 1891

\begin{tabular}{|c|c|c|c|c|c|c|}
\hline Year & 1842 & 1851 & 1861 & 1870 & 1891 & 1901 \\
\hline \multicolumn{7}{|l|}{ Religion } \\
\hline Church of England & 60.70 & 64.20 & 54.7 & 53.4 & 51.70 & 48.60 \\
\hline Church of Scotland & 6.60 & 6.40 & 10.0 & 9.1 & 6.90 & 6.70 \\
\hline Wesleyan Methodists & 3.90 & 5.40 & 6.9 & 7.2 & 12.10 & 14.50 \\
\hline Other Protestants ${ }^{1}$ & 3.30 & 3.40 & 4.5 & 4.9 & 5.50 & 5.90 \\
\hline Roman Catholics & 7.80 & 17.70 & 21.6 & 22.4 & 18.20 & 17.60 \\
\hline Jews & 0.50 & 0.60 & 0.4 & 0.2 & 0.06 & 0.06 \\
\hline Other $^{2}$ & 0.05 & 0.03 & 1.9 & 2.9 & 5.50 & 4.70 \\
\hline Religion not stated ${ }^{3}$ & 17.00 & 2.20 & 0.0 & 0.0 & 0.00 & 2.00 \\
\hline Total (\%) & 100.00 & 100.00 & 100.0 & 100.0 & 100.00 & 100.00 \\
\hline Total (no.) & 57,420 & 70,130 & 89,977 & 99,328 & 141,493 & 172,475 \\
\hline
\end{tabular}

${ }^{1}$ In 1842 and 1851, 'Other Protestant' includes 'Other Protestant dissenters' and, in 1861, 1870 and 1891, 'Independents' and 'Baptists'.

2 In 1842 and 1851, 'Other' includes 'Mahommedans and Pagans'; in 1861, 'Other sects'; in 1870, 'Mahommedans and Pagans', 'Society of Friends' and 'Other sects'; and in 1891 and 1901, 'Mahommedans, Buddhists and other non-Christian sects', 'Society of Friends', 'Other Christian sects' and 'Salvation Army'.

${ }^{3}$ In 1842, 'Religion not stated' includes 'Employed in government vessels', 'Convicts on public works', 'Convicts at penal settlements on Tasman's Peninsula' and 'Female convicts in house of corrections Hobart'. In 1851, 'Religion not stated' includes 'Military including women and children' and 'Convicts on public works'.

Sources: TAS (1851; 1861; 1870; 1891: 01_xlvii; 1901: 02_Ivii).

Religious affiliation may have been more fluid in a rapidly evolving society such as Tasmania than in 19th-century Britain and Western Europe. In the 1830s and 1840s, before the various denominations were able to establish churches or ministries throughout the colony, people in country areas would attend a church service even though they belonged to another Christian denomination (Breward 1988). This practice may have continued in the later half of the 19th century in the newly opened areas of settlement, such as the mining towns of Zeehan and Queenstown. People also changed their religious denomination during their lifetimefor instance, with Presbyterians becoming Anglicans and Anglicans becoming Methodists (Breward 1993; Critchett 2012a). 


\section{Education}

In the early years of the colony, children's education was provided in a variety of ways: the gentry sent their sons to England for schooling or their sons and daughters had tutors or governesses; there were a number of private fee-paying schools for young ladies and gentlemen; church schools were publicly funded; and small numbers of government schools were established (Grundy and Yuan 1987; Roe and Robson 1997; Reynolds 2010). All schooling, whether public or private, required some monetary contribution from parents. The Board of Education was set up in 1839 to fund and supervise the government schools (Sprod 1984). In 1840, there were 25 schools under the Board of Education, with 1,046 students enrolled.

In 1868, Tasmania became the first Australian colony to have a compulsory state education system, administered by local school boards. This meant girls as well as boys were required to receive an education. Under the 1868 Education Act, children aged seven to 12 years who lived within a mile of the school in 'settled districts' were required to attend school unless they were being educated privately, could read and write, were in poor health or their parents depended on their labour (Sprod 1984). In 1873, the Public Schools Amendment Act made it compulsory for all children seven to 14 years of age in all districts living within 2 miles ( 3 kilometres) of a public school to be sent to a public or private school. The local school board was given the discretion to exempt any child, and children 12 years and older were exempt if they were employed by their parents or others.

The Tasmanian Education Act of 1885 set up the Department of Education, which worked to improve the education system. The Act also required children to attend school for three days a week, which was amended to five days in 1898 (Sprod 1984). Several exemptions from compulsory schooling were, however, still in force during this period. The education system and school attendance improved from 1905, when Thomas Neale, the new Director of Education, began to reform the public education system. School fees were abolished in 1908 and state education became free.

Absenteeism was a problem throughout the final three decades of the 19th century. While the number of schools and average enrolments almost tripled between 1870 and 1901, average daily attendance as a proportion of average enrolments remained the same throughout the three decades- 
around 70-75 per cent (Table 3.7). Attendance, however, had improved with the introduction of compulsory education in 1868. Kippen (2002c: 210) estimated that school attendance for children aged seven to 13 years probably increased from less than 30 per cent to around 70 per cent between 1860 and 1900, suggesting compulsory education had a major impact on daily attendance in the late 1860 s.

Table 3.7 State school students and attendance, Tasmania, 1870, 1881, 1891 and 1901

\begin{tabular}{|c|c|c|c|c|}
\hline Year to 31 December & 1870 & 1881 & 1891 & 1901 \\
\hline Schools & 128 & 175 & 244 & 338 \\
\hline Average enrolments $^{1}$ & 6,678 & 9,258 & 13,491 & 19,236 \\
\hline Average daily attendance & 5,041 & 6,701 & 9,680 & 14,259 \\
\hline
\end{tabular}

${ }^{1}$ Average number of students on the roll. This was an average of the monthly, weekly or quarterly enrolments.

Source: Grundy and Yuan (1987: 337).

Government schools were generally attended by children of the lower middle class, skilled workers, small to medium farmers and the urban and rural working classes. Upper middle-class families tended to send their children to private academies and colleges, while the gentry sent their children to 'grammar' schools (Sprod 1984: 24). Catholic families sent their children to Catholic schools, regardless of social class.

Sprod (1984) concluded that the children of the urban and rural working classes and small farmers were the ones who did not attend government schools regularly during the later decades of the 19th century. Most of these children were working on the family farm, looking after younger children and doing domestic chores or working in paid employment outside the family home to supplement the family's income. Although the Tasmanian Women's and Children's Employment (Factories) Act of 1884 forbade the employment of children under the age of 12 years in factories, it specifically excluded seasonal work in the jam factories (Sprod 1984). Children aged 12 years and older were legally allowed to work in factories despite being required by law to attend school until they were 14 years of age. This Act was amended in 1905 so that '[n]o person under the age of Thirteen years shall be employed in any factory' (TAS 1905).

Even though some children's school attendance was irregular, they did attend school for some of the time and received at least a basic education. The literacy status of the population improved markedly during the second 
half of the 19th century, with the proportion of the total population that could read and write increasing between 1861 and 1901 (Table 3.8). The literacy status of the population was not published prior to 1861 and, for the years 1861 and 1870, it was not disaggregated by age or sex. Between 1881 and 1901, the proportion of the population aged 20 and over that was literate increased from 79 per cent to 92.1 per cent. In 1901, almost all the population aged 15-20 years could both read and write. Children's literacy also improved between 1881 and 1901.

Table 3.8 Proportion of the population who could read and write, Tasmania, 1861, 1870, 1881, 1891 and 1901

\begin{tabular}{|l|r|r|r|r|r|}
\hline Year & \multicolumn{1}{|c|}{1861} & 1870 & 1881 & 1891 & \multicolumn{1}{c|}{1901} \\
\hline Age & \multicolumn{5}{|c|}{ Percentage } \\
\hline All ages & 53.7 & 56.3 & 64.7 & 70.3 & 77.5 \\
\hline 5-15 years & n.a. & n.a. & 61.6 & 67.0 & 76.2 \\
\hline 15-20 years & n.a. & n.a. & 87.5 & 95.5 & 96.6 \\
\hline 20+ years & n.a. & n.a. & 79.0 & 87.4 & 92.1 \\
\hline
\end{tabular}

n.a. not available

Sources: TAS (1881: 02_45, 02_55; 1891: 04_89, 04_90; 1901: 02_li).

In relation to further education, the first technical school was established in Hobart in 1888, the University of Tasmania opened in the Hobart Domain in 1890 and a School of Mines and Metallurgy was set up in Zeehan in 1892 by the miners themselves (Robson and Roe 1997). A teachers' training college was established in Hobart in 1906 with the reform of the public education system.

\section{Occupation}

Occupational data from various colonial censuses and the first Australian census of 1911 (Appendix A: Tables A.7-13) reflect the economic changes that occurred in Tasmania in the 19th and early 20th centuries. They also show the marked growth in white-collar and more 'modern' occupations in the final two decades of the 19th century.

The occupational categorisations varied somewhat in each census, so the data are not strictly comparable. However, the broad occupational data show the dominance of agriculture between 1842 and 1870, the growth in the importance of industry and mining in the 1880s and 1890 s and the emergence of new occupations-for instance, in transport 
and communication-in these years. Agriculture clearly declined in importance during the final decades of the 19th century, with the proportion of the population employed in agriculture falling from around 50 per cent in 1851, 1861 and 1870 to around 33 per cent in 1891, 1901 and 1911 (Appendix A: Tables A.7-10). More detailed occupational data (discussed below) show the growth of white-collar occupations in the late 19 th and early 20th centuries.

Data for occupation by age and sex were published only from 1881 . Data on adult men's occupations for 1881, 1891 and 1901 are difficult to compare, since the classifications changed in each census (Appendix A: Tables A.11-13). People who were not employed were classified as 'Indefinite and non-productive' in the 1881 census, but in the two later censuses, the population was divided into 'Breadwinners' and 'Dependants', with 'Breadwinners' classified by occupation. There were several other changes within the occupational categories. Miners, for instance, were classified as 'industrial' in the 1881 census, but as 'primary producers' in later censuses. In 1901, occupations related to transport and communication, which were previously in the 'commercial' category, were given their own separate category, reflecting the growth of these more 'modern' occupations (Appendix D: Story 3).

It is difficult to obtain precise numbers showing the changes in occupations between 1881 and 1891 because of the changes in occupational classifications at the detailed level (TAS 1881:20_190-6; 1891:04_290_ 318; 1901: 05_394-426). However, there was clearly a rise in the number of men employed in white-collar occupations during this period. 'Accountant', for instance, was not an occupational classification in 1881, but there were 162 males employed as accountants in 1891 and 257 in 1901. This was an increase of 57 per cent, compared with an increase of 17.9 per cent in the number of male breadwinners. The number of men employed as 'Agents' - for example, for commission, insurance and sewing machines_-also rose markedly between 1881 and 1901, as did the number of 'Clerks' and 'Messengers'. The number of males who were 'Railway clerks and stationmasters' grew more than threefold, from 53 in 1881 to 117 in 1891 and to 185 in 1901 . This compares with an increase of 44 per cent in the population of males aged 15 years and older over the same period. The number of schoolteachers, both men and women, almost doubled between 1881 and 1901, from 602 to 1,109. 
There is no information about married women's occupations in any of the colonial censuses. In 1881, of the 26,181 women aged 20 years and older, 82 per cent were classified as 'domestic' (TAS 1881: 02_139). Around three-quarters of this group were 'wives and widows with no occupation specified' (TAS 1881: 02_142). It is not possible to tell whether women classified in specific occupations were married or single. In the 1891 census, of the 33,963 women aged 20 years and older, three-quarters were classified as 'dependants', with the remainder 'breadwinners' (TAS 1891: 04_175). The largest group of breadwinners (41.1 per cent) was classified as 'domestic'. McDonald and Quiggin (1985) note that, for the 1891 colonial censuses, colonial statisticians instructed that a woman should be recorded under 'domestic duties' if there was any doubt about her occupation (McDonald and Quiggin 1985: 80). The 1901 Tasmanian census had a similar occupational classification for women.

It appears that in 19th and early 20th-century Tasmania, most married women did not work outside the home, family business or farm. Working on the family farm or in the family shop or hotel, however, was probably reasonably common, as indicated by newspaper articles of the time. Some women did outwork, taking in washing and sewing. In the later part of the 19th century, some married women also worked as schoolteachers. Many married women also worked locally as midwives (Fahy 2007).

The 1911 census, which provides data on women's occupations by marital status, supports this view (Appendix A: Table A.14). Only a small proportion of married women ( 4.7 per cent) were classified as 'breadwinners', with the largest group working in the 'domestic category', supplying board and lodging or domestic services. 'Breadwinners' included those who were 'assisting (not receiving wages)', most of whom were married women working in lodging houses and shops and on farms.

\section{Urbanisation}

Prior to 1881, the Tasmanian censuses did not provide information on the population of any of the towns/cities except Hobart and Launceston. The censuses gave the population of electoral districts such as Campbell Town, which included both a town and its surrounding areas. It is difficult to tell the proportion of the population living in various districts prior to 1857 , because the precise locations of the convicts and the military population were not stated. 
In 1857, the population of Hobart was 18,258, accounting for 22.6 per cent of the colony's population (excluding the military), while the population of Launceston was much smaller, at 7,874 or 9.7 per cent (TAS 1857). In Tasmania, unlike the other Australian colonies, and reflecting its dependence on agriculture and mining, the proportion of its population living in its capital city, Hobart, did not grow markedly during the 19th century (McCarty 1974). Instead, there was marked growth in the north of the colony. In the late 1870s and 1880s, new towns were established in the north through the expansion into new areas for agriculture, sawmilling and mining (Meikle 2010). It was possible to export from Launceston and from the smaller northern towns of Devonport and Burnie (Burnley 1980). Launceston grew by 62 per cent between 1857 and 1881 compared with Hobart's growth of 15.7 per cent (TAS 1861; 1881: 02_30). Hobart's population may have been understated in 1881, however, since in that year there were several towns adjoining Hobart that by the 1891 and 1901 censuses were classified as 'suburbs of Hobart' (Appendix A: Table A.15).

Between 1881 and 1901, the population of the 'metropolis' of Hobart grew from 21,118 to 24,654 (16.7 per cent), but an additional 7,764 people resided in the Hobart suburbs in 1901 (Appendix A: Table A.15; TAS 1901: 02_viii). In the far west, mining towns such as Zeehan and Queenstown grew spectacularly in the final two decades of the 19th century (Appendix A: Table A.15). Queenstown, which was not even included in the 1891 census, had a population of 5,051 by 1901 , while Zeehan grew from 1,965 to 5,014 over the same period. Towns in the north of the colony such as Burnie, Devonport and Ulverstone also grew markedly, while towns in the Midlands, such as Campbell Town and Oatlands, either declined or stagnated. By 1901, there were 27 towns with populations of 500 or more (excluding Hobart and Launceston), most of them close to one another and to the larger cities of Hobart and Launceston. At the same time, there were small settlements, such as Marrawah on the far north-western coast, which were very remote (Appendix D: Story 2). By 1901, 30.1 per cent of Tasmania's population was living in Hobart and Launceston and their suburbs, 21 per cent lived in other towns of 500 people or more and 48.9 per cent lived in the remainder of the state. 


\section{Summary}

In its first 50 years, the colony's history was dominated by convict settlement, but after transportation ceased in 1853, the convict society began to die out. By 1857, free settlers or people born in the colony accounted for most of the population. Convicts made up only a very small proportion of the population.

Tasmania was highly dependent on agriculture in its early years, but from the 1870s, mining emerged as a major industry. The colony was prosperous from settlement until the mid-1850s, when a depression set in, but this lifted in the early 1870 s with the mining discoveries. Like most other colonies, Tasmania experienced a great depression in the early 1890 s, but the economy improved at the end of the 19th century and in the early 20th century. The late 19 th and early 20 th centuries were a time of great social and economic change for the colony, with improvements in communication and transportation, the introduction of electricity to cities, compulsory primary school education and universal suffrage.

By the final decade of the 19th century, a high proportion of the population was born in Tasmania and was literate. There was a large rise in white-collar and 'modern' occupations, communication was good and news from other colonies and overseas reached Tasmania with very little delay. The population was not strongly religious and there was a relatively high urban orientation.

It is against this backdrop that the historical fertility decline took place. 
This text is taken from Australia's Fertility Transition: A study of 19th-century Tasmania, by Helen Moyle, published 2020 by ANU Press, The Australian National University, Canberra, Australia.

doi.org/10.22459/AFT.2020.03 